Zeszyty Naukowe Szkoły Głównej Gospodarstwa Wiejskiego w Warszawie

Problemy Rolnictwa Światowego tom 17 (XXXII), zeszyt 2, 2017: 65-80

DOI: 10.22630/PRS.2017.17.2.27

Grębowiec Mariusz ${ }^{1}$

Szkoła Główna Gospodarstwa Wiejskiego w Warszawie

\title{
Produkty regionalne i tradycyjne jako element budowania konkurencyjnej oferty produktów żywnościowych w Polsce i innych krajach Europy
}

\section{Regional and Traditional Products as an Element of Building a Competitive Food Product Offer in Poland and Other European Countries}

\begin{abstract}
Synopsis. Celem opracowania było ukazanie współczesnego miejsca produktów regionalnych i tradycyjnych na współczesnym jednolitym rynku europejskim. Przybliżono zmiany zachodzące na tym rynku w ilości zarejestrowanych produktów regionalnych zarówno w Polsce jaki i innych krajach europejskich. Ponadto podkreślono projakościową i prozdrowotną rolę jaką przypisuje się tego typu żywności, na zróżnicowanym i zdominowanym przez masowe produkty rynku. Uwypuklono także marketingowy wymiar funkcjonowania tego rynku, zwracając uwagę na współczesne sposoby promowania tego typu produktów, jak również pokazano główne sposoby sprzedaży tej żywności. Ponadto zwrócono uwagę na główne czynniki brane pod uwagę w procesie zakupu jak również identyfikacji żywności tradycyjnej i regionalnej przez nabywców. Rozważania teoretyczne zostały poparte badaniami ankietowymi na grupie 360 przypadkowo dobranych osób za pośrednictwem internetu.
\end{abstract}

Slowa kluczowe: produkt regionalny, produkt tradycyjny, systemy ochrony jakości, oferta konkurencyjna

\begin{abstract}
The aim was to show the place of regional and traditional products in the contemporary European single market. The changes taking place in this market were reflected in the number of registered regional products in both Poland and other European countries. In addition, the proquality and health-promoting role of such foods is now emphasized, nowadays so diverse and dominated by mass market products. The marketing dimension of this market has also been emphasized, paying attention to contemporary ways of promoting this type of product, as well as showing the main ways of distributing the food. In addition, attention was paid to the main factors taken into account in the purchase process as well as the identification of traditional and regional food by purchasers. Theoretical considerations were backed up by a survey of 360 randomly selected individuals via the Internet.
\end{abstract}

Key word: regional product, traditional product, protection of quality system, competitive offer

\section{Wprowadzenie}

Różnorodność kulturowa państw i regionów Europy to wielki atut. Dlatego też istnieje idea ochrony produktów rolnych, związana $\mathrm{z}$ tradycyjną produkcją

\footnotetext{
${ }^{1}$ dr inż., Katedra Polityki Europejskiej i Marketingu SGGW, ul. Nowoursynowska 166, 02-787 Warszawa, e-mail: grebowiecmariusz@poczta.onet.p1
} 
i pochodzeniem geograficznym produktów wytwarzanych w różnych regionach Unii Europejskiej.

Polska to kraj o wielkich tradycjach, mający doskonałe warunki do wytwarzania produktów żywnościowych o wysokiej jakości i niepowtarzalnych parametrach smakowych. Wiejski krajobraz oraz różnorodność biologiczna stanowią doskonałą podstawę do rozwoju rynku żywności o tradycyjnym charakterze. Konsumenci coraz częściej decydują się na zakup produktów regionalnych w celu m.in.: poznania smaków danego regionu. Produkty tradycyjne i regionalne charakteryzują się wysoka jakością i określonym składem chemicznym, dlatego dla osób dbających o zdrowe odżywianie, jest to ciekawa propozycja.

Niestety na rynku znajduje się coraz więcej podrabianych produktów, imitujących oryginalne produkty regionalne i tradycyjne. Posiadaja one jednak zmieniony skład chemiczny i walory zdrowotne. Dlatego Unia Europejska, aby temu zapobiec wprowadziła w 1992 roku dwa systemy umożliwiające ochronę produktów regionalnych i tradycyjnych.

Z punktu widzenia nabywcy, istnieje wiele czynników jakimi kierują sie oni przy wyborze produktów tradycyjnych i regionalnych. Można podzielić je na trzy grupy, mianowicie są to czynniki ekonomiczne, społeczno-kulturowe oraz psychologiczne. Jednak przy określeniu preferencji konsumenta trzeba zawsze pamiętać o tym, że każda jednostka jest inna i nie jest łatwo dokładnie określić, co nią kieruje przy wyborze tego typu produktów.

\section{Europejski system ochrony jakości produktów regionalnych i tradycyjnych}

Za sprawą rozwoju rynku produktów regionalnych i tradycyjnych, nie tylko ich producenci ale również konsumenci mogą uzyskać korzyść jaką jest m.in. bezpieczeństwo żywności. W tym celu został stworzony system identyfikacji, ochrony i promowania produktów regionalnych i tradycyjnych (Borowska, 2009). Bowiem produkty te posiadają określone pochodzenie geograficzne i metodę wytworzenia. Główną przyczyną powstania odrębnych przepisów było zapewnienie produktom ochrony przed podróbkami, które wprowadzałyby w błąd konsumenta. Ważnym aspektem było także stworzenie mechanizmu, który oferuje mieszkańcom danego regionu promocję swoich miejscowych wyrobów, co wpływa jednocześnie na promowanie regionu. Producenci, oprócz ochrony nazwy, mogą umieszczać na opakowaniu symbole informujące o wyjątkowości produktu.

Wygląd symbolu jest wszędzie taki sam i obowiązuje w całej Unii Europejskiej. Ich rozpoznawalność w Europie sięga kilkunastu procent. Pomysł znakowania przejęto z francuskiej ochrony nazw geograficznych, co wpłynęło na bezpieczeństwo produktu i większą sprzedaż w ciaggu kilkudziesięciu lat. Na tej podstawie stworzono stosowne rozporządzenia, które umożliwiły wprowadzenie na europejski rynek trzech oznaczeń dotyczących ochrony i podkreślania wyjątkowości produktów tradycyjnych i regionalnych (Rzytki, Jasiński, 2005). Zaliczają się do nich:

- Chroniona Nazwa Pochodzenia (ChNP),

- Chronione Oznaczenie Geograficzne (ChOG), 
- Świadectwo Specyficznego Charakteru (Gwarantowana Tradycyjna Specjalność) - GTS (http://coie.armsa.pl/Mazovian,regional,products,130.html).

Wspólnotowe symbole mogą być używane na produktach lub materiałach reklamowych i promocyjnych, wyłącznie zgodnie z ustalonymi zasadami.

Muszą zaistnieć okoliczności, w których dany produkt może otrzymać stosowne oznaczenie. Proces tworzenia idei produktów regionalnych i tradycyjnych to długoletnia praca mieszkańców w każdym kraju. Do znaków Unii Europejskiej indywidualny producent nie ma prawa, tylko grupa przetwórców lub producentów. Szczególnym przypadkiem jest sytuacja, w której brak na danym obszarze renomowanych producentów, w takiej sytuacji osoba fizyczna lub prawna będzie postrzegana jako grupa (nie dotyczy GTS).

Rejestracja produktu jest dwuetapowa. Pierwszym etapem procesu harmonizacji jest rejestracja na poziomie krajowym. Rozpoczyna się ona od określenia zasad wytwarzania produktu, oraz reguł kontroli obowiązujących grupę. Grupa wysyła wniosek do Ministerstwa Rolnictwa i Rozwoju Wsi, gdzie zostaje on rozpatrzony (maksymalnie do 14 dni). Następnie jest czas na poprawienie ewentualnych błędów (14 dni) i streszczenie wniosku. Wniosek zostaje zamieszony na stronie internetowej Ministerstwa, w celu składania zażaleń (30 dni). Gdy one występują odbywa się wyjaśnienie, uzgadnianie i doprowadzenie do konsensusu. Jeśli zaś nie ma, wówczas wniosek przekierowany jest do Rady do Spraw Tradycyjnych i Regionalnych Nazw Produktów Rolnych i Sródków Spożywczych (ocenia go Minister Rolnictwa i Rozwoju Wsi). Jeśli wniosek zostaje zaakceptowany, wysyła się go do Komisji Europejskiej. Wnioskowany produkt posiada już tymczasową krajową ochronę.

Drugi etap następuje na poziome wspólnotowym. Cały proces w Unii Europejskiej jest identyczny, jak przy rejestracji krajowej. Następnie określony jest czas na sprzeciwy i porozumienie stron. Podjęcie decyzji przez Komisję Europejką nie przekracza 6 miesięcy. Certyfikat i rejestrację w systemie Unii Europejskiej otrzymuje określona grupa producentów. Jednakże, każdy producent aspirujący o znaki i nazwę produktu musi liczyć się z inspekcjami, które będą badać proces produkcji (czy jest on zgodny z harmonogramem rejestracji). Przykładami jednostek kontrolujących mogą być: Inspektor Jakości Handlowej Artykułów Rolno-Spożywczych, bądź prywatna jednostka certyfikująca wybierana przez Ministra Rolnictwa i Rozwoju Wsi. Proces kontroli odbywa się $\mathrm{w}$ miejscu produkcji, poprzez pobieranie próbek wytwarzanego produktu i ich analizy w laboratorium (Winawer, 2013).

\section{Budowanie konkurencyjnej ofert regionów na bazie produktów regionalnych i tradycyjnych}

Konkurencyjność definiowana jest jako potencjał możliwości oraz umiejętność danego podmiotu rynkowego do sprostania konkurencji. Ta z kolei oznacza proces prowadzący do przedstawienia konsumentom własnej oferty jako korzystniejszej od innych z tej samej branży. Rywalizujące jednostki dążą do takich samych korzyści, w tym samym czasie i przy takich samych regułach, a realizacja interesów jednych zagraża realizacji interesów pozostałych (Mynarski, 2001). Konkurencyjność określa pozycję danego podmiotu z punktu widzenia jego zasobów, możliwości, szans i 
potencjału w stosunku do struktury rynku. Może się przejawiać w zdolności do (Faulkner, Bosman, 1996) oferowania niższych cen oraz wyższej jakości cech wyróżniających produkt, utrzymania i powiększania udziałów w rynku, podnoszenia wewnętrznej efektywności funkcjonowania przedsiębiorstwa, skutecznego realizowania celów na rynku. Konkurencyjność może odnosić się nie tylko do przedsiębiorstw, ale także do określonych przestrzeni (państw, regionów, miejscowości) z punktu widzenia ich rozwoju gospodarczego (Faulkner, Bosman, 1996; Czyż, 2009). Oznacza w takim przypadku rolę, którą może odegrać region w gospodarce danego kraju lub wspólnoty państw. Do czynników decydujących o konkurencyjności regionu można zaliczyć, takie jak: lokalizacja geograficzna, zasoby naturalne, stopień otwartości rynku, jakość kapitału ludzkiego, infrastruktura, zagraniczne inwestycje bezpośrednie, instytucje formalne i nieformalne, warunki demograficzne, dopasowanie popytu i podaży czynnika pracy oraz innowacje (Golejewska, Gajda, 2012). Ich istnienie częściowo wynika $\mathrm{z}$ uwarunkowań historycznych, ale $\mathrm{w}$ większym stopniu zależy od aktywności władz samorządowych $w$ sferze planowania i wdrażania polityki regionalnej oraz od polityki gospodarczej (w tym rolnej) państwa (Richter-Kaźmierska, 2007). Specyfika regionalnej żywności tradycyjnej powoduje, że w jej przypadku konkurencyjność można rozpatrywać zarówno $\mathrm{z}$ punktu widzenia przedsiębiorstw wytwarzających produkty tradycyjne, jak i regionów, z których kulturą kulinarną jest nierozerwalnie związana. W takich regionach konkurencyjność opiera się na atrakcyjnych zasobach naturalnych $\mathrm{i}$ walorach wynikających $\mathrm{z}$ dziedzictwa kulturowego (w tym kultury kulinarnej) oraz na ich odpowiednim wyeksponowaniu i wykorzystaniu.

Wypromowanie produktów regionalnych pozwala zyskać źródło dodatkowych lub głównych dochodów i zmniejszyć bezrobocie nie tylko doraźnie, ale także w przyszłości. Uzyskaniu przewagi konkurencyjnej na rynku żywnościowym oraz osiagnnięciu silnej pozycji sprzyja także krajowy i europejski system prawny chroniący wyroby tradycyjne i regionalne, dający szanse wszystkim unijnym producentom ochrony specyficznych produktów rolnych lub artykułów żywnościowych. Pozwala to producentom zapewnić monopol na lokalnych rynkach oraz osiagać wyższe dochody $\mathrm{w}$ zamian za starania na rzecz zachowania jakości produktów regionalnych przez stosowanie niezmienionych od lat receptur i procesów technologicznych. Wiele z tych produktów wytwarzanych jest $\mathrm{w}$ warunkach gospodarstw rolnych, stanowiąc atrakcje przyciągającą turystów i stwarzających szansę rozwoju agroturystyki (Świstak i in., 2013). Badania prowadzone wśród konsumentów żywności tradycyjnej, wskazuja, że miejsce zakupu ma dla nich istotne znaczenie i może być wykorzystane dla zwiększenia jej popularności. W jednym z badań (Konkurencyjność..., 2014) na pytanie, przy jakich okazjach spożywane są produkty regionalne i tradycyjne najwięcej respondentów $(75 \%$ badanych) odpowiedziało, że podczas pobytu w regionie wytwarzania danego produktu. Jednocześnie tylko nieliczni respondenci potrafili wymienić więcej niż pięć produktów regionalnych, co świadczy o potrzebie ich popularyzacji. Atrakcyjnym rozwiązaniem w zakresie promocji produktów tradycyjnych oraz oferujących je regionów mogą być podróże kulinarne odbywane w poszukiwaniu oryginalnych potraw i produktów lub $\mathrm{w}$ celu powrotu do smaków dzieciństwa (Krajewski i in., 2009). Jeśli trwają one dłużej, bywają połączone $\mathrm{z}$ wypoczynkiem $\mathrm{np}$. w gospodarstwach agroturystycznych, oferujących często nie tylko możliwość konsumpcji potraw tradycyjnych i regionalnych, ale także uczestnictwo $\mathrm{w}$ ich przygotowywaniu. W czasie krótszych 
podróży lub tylko przejazdów przez regiony z rozpoznawalną kuchnią rośnie znaczenie lokalnej gastronomii jako czynnika promocji żywności tradycyjnej przez serwowanie oryginalnych potraw regionalnych lub dań przygotowywanych na ich bazie.

\section{Produkty regionalne i tradycyjne w Polsce i innych krajach Europy}

Do chwili obecnej (2017) w całej Europie znaki jakości przypisano do 1377 produktów tradycyjnych i regionalnych. W Krajach Unii Europejskiej zarejestrowano około 1355 produktów (najwięcej ChNP - 613, ChOG - 688 i najmniej GTS - 54) i w krajach z poza Unii - 22 produkty (ChNP - 6, ChOG - 16 i GTS - brak).

Tabela 1. Liczba produktów zarejestrowanych, jako ChNP, ChOG i GTS w krajach należących do Unii Europejskiej - (stan na dzień 21 listopad 2016 roku)

Tabele 1. Number of products registered as PDOs, PGIs and GTS in EU countries - (as of 21 November 2016)

\begin{tabular}{|c|c|c|c|c|}
\hline Kraj & ChNP & ChOG & GTS & Liczba produktów \\
\hline Włochy & 165 & 121 & 2 & 288 \\
\hline Francja & 98 & 138 & 1 & 237 \\
\hline Hiszpania & 101 & 88 & 4 & 193 \\
\hline Portugalia & 64 & 72 & 1 & 137 \\
\hline Grecja & 75 & 29 & 0 & 104 \\
\hline Niemcy & 12 & 77 & 0 & 89 \\
\hline Wielka Brytania & 24 & 34 & 3 & 61 \\
\hline Polska & 8 & 19 & 9 & 36 \\
\hline Czechy & 6 & 23 & 4 & 33 \\
\hline Słowenia & 8 & 11 & 3 & 22 \\
\hline Belgia & 3 & 10 & 5 & 18 \\
\hline Austria & 10 & 6 & 1 & 17 \\
\hline Chorwacja & 8 & 7 & 0 & 15 \\
\hline Holandia & 6 & 5 & 3 & 14 \\
\hline Słowacja & 1 & 10 & 3 & 14 \\
\hline Węgry & 6 & 7 & 1 & 14 \\
\hline Finlandia & 5 & 2 & 3 & 10 \\
\hline Szwecja & 3 & 3 & 2 & 8 \\
\hline Bułgaria & 0 & 3 & 4 & 7 \\
\hline Irlandia & 3 & 4 & 0 & 7 \\
\hline Litwa & 1 & 4 & 2 & 7 \\
\hline Cypr & 2 & 4 & 0 & 6 \\
\hline Dania & 0 & 6 & 0 & 6 \\
\hline Łotwa & 1 & 1 & 3 & 5 \\
\hline Luksemburg & 2 & 2 & 0 & 4 \\
\hline Rumunia & 1 & 2 & 0 & 3 \\
\hline Estonia & 0 & 0 & 0 & 0 \\
\hline Malta & 0 & 0 & 0 & 0 \\
\hline Razem & 613 & 688 & 54 & 1355 \\
\hline
\end{tabular}

Źródło: Opracowanie własne, na podst. Rolnictwo i rozwój obszarów wiejskich, DOOR - Database of Origin and Registration; www.ec.europa.eu. 
Niezmiennie dominującymi w liczbie certyfikowanych produktów są prekursorzy tych oznaczeń, czyli Włochy i Francja. Natomiast Polska wyróżnia się na tle Unii Europejskiej tym, że posiada najwięcej produktów z certyfikatem GTS.

Na dzień 21 listopada 2016 roku 22 produkty pochodziło z krajów nienależących do Unii. W ich skład wchodzą: Dominikana - 1 produkt, Turcja - 1, Tajlandia - 4, Kambodża - 1, Andora - 1, Chiny - 10, Kolumbia - 1, Wietnam - 1, Indie - 1 .

Mając na uwadze różne kategorie produktowe (zestawione $\mathrm{w}$ klasach punktowych), najwięcej produktów występuje w klasie 1,6 - owoce i warzywa, jest to aż 366 produktów. Drugą co do liczebności klasą jest kategoria 1,3 - sery. W obu klasach punktowych dominującymi krajami są:Włochy, Hiszpania i Francja.

Do najbardziej znanych produktów na rynku europejskim należą:

- Gorgonzola, Mozzarella di Bufala, Parmigiano Reggiano, czyli parmezan, szynka parmeńska (Włochy)

- sery takie jak Camembert de Normandie i Roquefort (Francja)

- ser feta oraz oliwy z oliwek (Olimpia - Grecja).

W 2005 roku wprowadzono w Polsce listę produktów regionalnych i tradycyjnych na której 20 lipca znalazł się kindziuk z Puńska (Podlasie) jako pierwszy oficjalny produkt tradycyjny i regionalny.

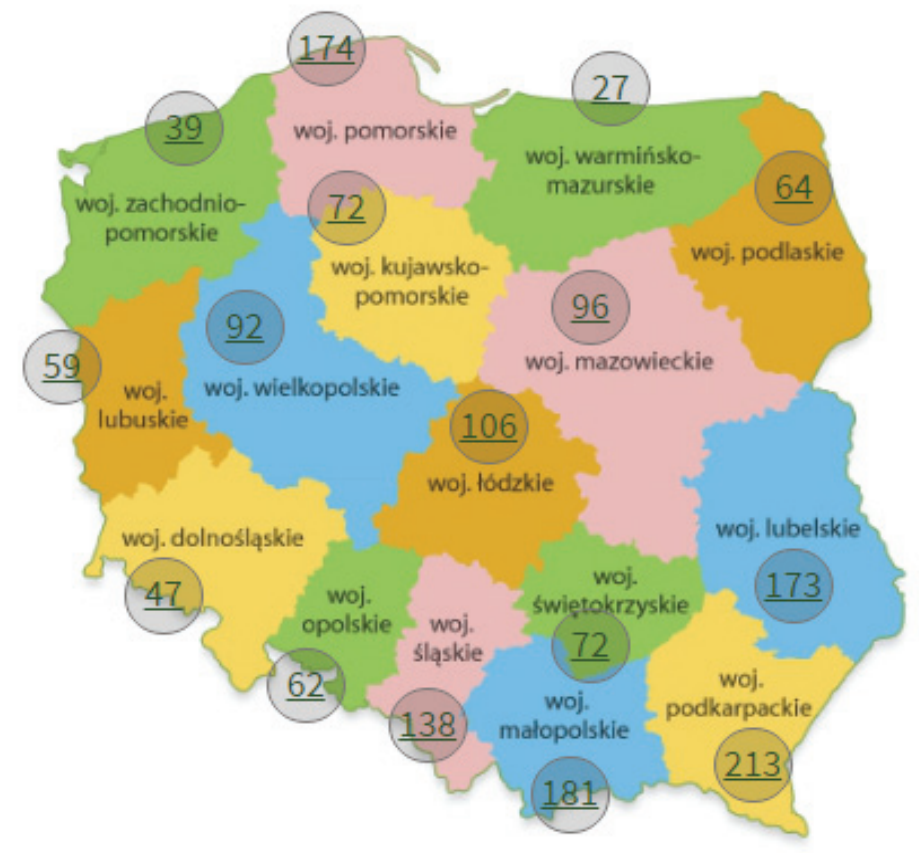

Rys. 1. Mapa produktów tradycyjnych w Polsce

Fig. 1. Map of traditional products in Poland

Źródło: http://www.minrol.gov.pl/Jakosc-zywnosci/Produkty-regionalne-i-tradycyjne/Lista-produktowtradycyjnych, dostęp w dniu 23.11.2016. 
Spośród 1615 produktów są takie, które uzyskały Certyfikację Unijną jako produkty $\mathrm{z}$ zakresu promowania dziedzictwa kulturowego. Było ich na dzień 22.11.2016 roku 36, w tym $\mathrm{z}$ :

- Chronioną Nazwą Pochodzenia -8 produktów,

- Gwarantowaną Tradycyjną Specjalnością -9 produktów,

- Chronionym Oznaczeniem Geograficznym - 19 produktów (coie.armsa.pl/ Mazovian,regional,products, $130 . \mathrm{html})$.

Dane liczbowe wskazują na to, że w Polsce istnieje duży potencjał rozwojowy. Natomiast, jak do tej pory ilość np. serów, nalewek, czy powideł wyprodukowanych w tradycyjny sposób, w sklepach jest niewielka, na co zwracają uwagę badania przeprowadzone m.in. przez Sieczko (2008). Wśród 250 badanych przez Autorkę respondentów $60 \%$ określa, że wybór żywności tradycyjnej i regionalnej jest mały lub bardzo mały, a tylko $6 \%$ odpowiedziało - duży. Może to być spowodowane wciąż słabą promocją oraz niską wiedzą konsumentów na temat żywności tradycyjnej i regionalnej, i okrojonym dostępem do tego typu żywności (Grębowiec, 2010).

Producenci żywności regionalnej i tradycyjnej, to najczęściej niewielkie firmy, które nie mają wpływu na cenę rynkową gdyż ich udział rynkowy jest zbyt niski. Na dodatek muszą produkować $\mathrm{w}$ sposób zgodny $\mathrm{z}$ zasadami oraz nie mogą swoich produktów modernizować. Producent nie ma możliwości stosowania nowoczesnej technologii, automatyzacji czy przyspieszania pewnych procesów (Sieczko, 2008).

\section{Rola marketingu w procesie identyfikacji żywności tradycyjnej i regionalnej w Polsce}

Bardzo ważnym działaniem, jest szerokie eksponowanie oznaczeń produktów regionalnych. Ponieważ jest to marketingowe umocnienie wizerunkowe terenów i gospodarki wiejskiej (Sylvander, 2002). Istnieje wiele korzyści wynikających z posiadania $w$ danym regionie produktów regionalnych $\mathrm{i}$ tradycyjnych, a mianowicie:

- wykorzystanie zasobów naturalnych oraz aktywizowanie miejscowej ludności, nakładów kapitałowych lub kulturowych, które zostały zablokowane lub nie są w pełni wykorzystywane,

- zwiększenie rozwoju regionu, wzmocnienie działalności gospodarczej,

- zróżnicowanie produktów w regionie,

- promocja regionu i dziedzictwa kulturowego,

- wprowadzanie nowych strategii działania, poprzez mobilizację lokalnych podmiotów,

- promocja dla małych firm (Czarnecki, 2012),

- zwiększenie wartości produktu i identyfikowalność,

- ochrona na terenie ojczystym i w całej Unii Europejskiej (Winawer, 2013).

Przy kreowaniu promocji obszaru warto zwrócić uwagę na to, że występuje wiele cech wpływających na wybór przez konsumenta produktów tradycyjnych i regionalnych. Przy promocji dziedzictwa kulturowego można korzystać z dwóch różnych modeli takich jak (Sieczko, 2014):

- pokazanie głównie regionu, miejsca, 
- $\quad$ wyjście od produktu (symbolu), imprez, ofert rynkowych.

Drugi model wydaje się być zdecydowanie właściwszy, ponieważ turyści wybierają miejsca poprzez atrakcje danego regionu. Natomiast produkty regionalne i tradycyjne to zasób, który często tworzy wartość dodaną danego miejsca.

Przykładem efektywnej promocji są działania województwa pomorskiego, które buduje markę i wizerunek danego miejsca, poprzez nowoczesną kulturę kulinarną i tradycyjne produkty. Realizowany był tam projekt zatytułowany: „Gdańsk Pomorskie Culinary Prestige", którego celem jest promowanie gastronomii lokalnej w Polsce, Niemczech i Skandynawii, poprzez produkty tradycyjne regionalne, jak również tworzenie konkurencyjnej i całorocznej oferty.

Świętokrzyskie aby promować swój region w 2011 roku wprowadziło projekt „Świętokrzyska Kuźnia Smaków”, który od 2015 roku został uruchomiony jako szlak kulinarny „Szlak Świętokrzyska Kuźnia Smaków”. Jego celem jest pokazywanie konkretnych miejsc sprzedaży i produkcji produktów regionalnych i tradycyjnych. Został umiejscowiony w czterech powiatach: sandomierskim, ostrowieckim, opatowskim i kieleckim w których na rok 2015 znajdowało się 9 restauracji, 21 gospodarstw rolnych i 4 gospodarstwa agroturystyczne, serwujące produkty regionalne. Ich zadaniem jest promowanie i eksponowanie tradycyjnych produktów oraz potraw (Sieczko, 2014).

Przykładowymi organizacjami pozarządowymi, które zaangażowane są w promocję i ochronę produktów regionalnych są: Europejska Sieć Regionalnego Dziedzictwa Kulinarnego, Slow Food, oraz Polska Izba Produktu Regionalnego i Lokalnego.

Polska może pochwalić się również wieloma szlakami turystyki kulinarnej np. Małopolski Szlak Owocowy, Szlak Oscypkowy, Lubuski Szlak Wina i Miodu, Szlak Kulinarny Kuchnia Polska, Szlak Janosika, Szlak Jadła Mazurskiego, Szlak Specjalnych Kuchni Kwater Wiejskich, Szlak Fasolowa Dolina, Podlaski Szlak Tatarski. Szlaki te mają na celu promocję zakładów gastronomicznych, poznanie tradycji kulinarnej, czy lokalnej promocji wybranych produktów czy też potraw (Stasiak, 2015).

W ciagu ostatnich lat, w Polsce narodził się pozytywny trend, jakim jest nabywanie żywności m.in. na lokalnych targach, czy jarmarkach. Zaletami takiej sprzedaży jest bezpośredni kontakt z klientem, możliwość zakupu po niższej cenie, jak również niższe straty w sprzedaży produktów. Jednym z pierwszych pomysłodawców organizowania jarmarków byli rolnicy z obrzeży Warszawy, którzy stworzyli „Otwarte Wrota”. Na jarmarkach odbywają się oprócz sprzedaży, prezentacje lokalnych i ekologicznych produktów. W kwietniu 2012 roku powstały „Regionalia”, które charakteryzują się ciekawymi stoiskami z produktami regionalnymi z Polski oraz świata. Odbywają się prezentacje regionów, produktów np. win. „Regionalia” oferują warsztaty z zakresu bezpieczeństwa żywności i e - marketingu. W ich trakcie wystawiane są stoiska $\mathrm{z}$ gastronomią wykorzystującą produkty regionalne. Inne znane jarmarki w Polsce to m.in.: „Biobazar” - Warszawa, „Jarmark Toruński”- Toruń, „BoZeWsi” - Trójmiasto i „Wrocław na zdrowie” - Wrocław.

Sprzedaż lokalnych produktów odbywa się w wielu większych miastach Polski. Przykładem może być „Specjał Wiejski”, który posiada sieć 8 sklepów w Warszawie i po jednym w Lublinie i Gdańsku. Produkty regionalne i tradycyjne są prezentowane na konkursach kulinarnych. Jednym z najbardziej znanych jest konkurs „Nasze Kulturowe 
Dziedzictwo - Smaki Regionów”. Celem konkursu jest poznanie i udokumentowanie specjałów narodowych, produktów tradycyjnych, tak aby nie dopuścić by poszły w zapomnienie (Przybylak, 2013).

Ważną rolę w promocji produktów regionalnych mają systemy oznaczeń Unijnych. Dla konsumenta jest to informacja, że określony produkt posiada wysoką jakość i ma tradycyjną recepturę wytwarzania. Najbardziej znanym polskim oznaczeniem jest „Jakość tradycja”. Określany jako system jakości żywności od 12 czerwca 2007 roku. Produkty opatrzone tym znakiem, mają charakterystyczny skład, określony sposób produkcji, bądź określoną jakość. Za tradycyjny produkt uważa się, taki który ma pięćdziesięcioletnią tradycję produkcji. Mogą go posiadać producenci indywidualni, jak i grupy producentów, czy zakłady za granica. Najważniejszymi elementami znaku „Jakości tradycja” są: jakość produktu, kontrola jakości, otwartość systemu i identyfikowalność produktu (Winawer, Wujec, 2010).

Współcześnie dominującym kanałem sprzedaży produktów regionalnych i tradycyjnych jest głównie kanał bezpośredni, szczególnie na rynkach lokalnych, m.in.: w prywatnych gospodarstwach rolnych, gospodarstwach agroturystycznych, restauracjach, jak również przy okazji lokalnych imprez, na których można dane produkty spróbować oraz nabyć. Do najczęściej kupowanych produktów zalicza się: mięsa i wyroby wędliniarskie, wyroby piekarnicze i cukiernicze, owoce warzywa i zboża, przetwory i soki owocowo - warzywne oraz sery. Rynek takich produktów musi się mierzyć $\mathrm{z}$ ciągłą niesprawnością dystrybucji, natomiast nie jest łatwo to przezwyciężyć (Krajewski, Zabrocki, 2008). Obecnie dystrybucja w Polsce z powodu niskiej świadomości istnienia i braku znajomości przez konsumentów produktów tradycyjnych jest utrudniona, a dostarczanie wyrobów na rynek nie jest zbyt opłacalne dla producentów. Szansą na zmianę tego stanu rzeczy jest Internet. Producenci mogą dotrzeć w ten sposób do większego grona nabywców, w tym głównie do osób młodych, młodych małżeństw, czy ich rodziców. Twórcą jednej ze stron internetowych zajmujących się dystrybucją zdrowej żywności jest Jan Czaja (odrolnika.pl). Inicjator miał na celu zrzeszenie ze sobą gospodarstw produkujących dane dobro i sprzedaż klientom z Krakowa i Warszawy. Inną stroną jest „wiemcojem.pl”, której twórca promuje i sprzedaje produkty regionalne i tradycyjne wytwarzane nie dalej niż $100 \mathrm{~km}$ od miejsca produkcji. Bardzo ciekawym rozwiązaniem jest serwis „lokalnespecialy.pl”, który działa tak jak klub konesera. Użytkownik zapisuje się na stronie i co miesiąc dostaje inny rodzaj produktu regionalnego do spożycia, najczęściej nie ma pojęcia co znajduje się w paczce. Strona jest skierowana głownie do koneserów i osób preferujących urozmaiconą dietę. Innymi stronami internetowymi zajmującymi sie promowaniem i sprzedażą są: „lokalnażywność.pl” lub „ekotarg.pl” (Przybylak, 2013).

\section{Wyniki badań}

Badania przeprowadzone na potrzeby niniejszego opracowania zostały zrealizowane na podstawie ankiety internetowej w kwietniu 2017 roku. Próba do badania została dobrana w sposób przypadkowy. Natomiast jako główne kryterium doboru próby do badania wzięto, pod uwagę fakt rozpoznawania przez respondentów produktów regionalnych i tradycyjnych oraz deklarowanie nabywania przez 
respondentów tejże żywności. Narzędziem badawczym był standaryzowany kwestionariusz ankiety. Zawierał on 20 pytań merytorycznych związanych z badanym zagadnieniem, jak również 4 pytania metryczkowe, które pozwoliły określić płeć, wiek, wykształcenie, miejsce zamieszkania respondenta. Kwestionariusz ankiety składał się z pytań zamkniętych jednokrotnego oraz wielokrotnego wyboru.

W badaniu wzięło udział 368 respondentów z czego po wstępnej analizie pod względem kompletności zebranego materiału badawczego i wyeliminowaniu niekompletnych, bądź źle wypełnionych kwestionariuszy do ostatecznej analizy wzięto pod uwagę informacje pozyskane od 360 respondentów. Przeprowadzone badania, ze względu na zbyt małą próbę badawczą, nie mają charakteru badań wyczerpujących.

Z pośród badanych, kobiety stanowiły $76 \%$ badanej populacji mężczyźni zaś $24 \%$. Najliczniejszą wiekowo grupę z spośród respondentów stanowiły osoby w wieku 18-30 lat (54\%), osoby w wieku 31-50 (23\% badanej populacji), osoby w wieku 51-65 lat stanowiły $17 \%$ badanych. Pozostałą część (około 6\%) stanowiły osoby powyżej 65 roku życia. Osoby $\mathrm{z}$ wykształceniem wyższym stanowiły $44 \%$ badanych, $\mathrm{z}$ niepełnym wyższym $(29,4 \%)$ oraz średnim $(21 \%)$. Najmniej osób posiadało wykształcenie podstawowe $3,1 \%$ oraz zawodowe $2,5 \%$. Najwięcej badanych pochodziło z miasta powyżej 500 tys. mieszkańców (26\%), następnie z miasta do 20 tys. mieszkańców (24\%), wsi (21\%), a najmniej (10\%) z miasta od 100 tys. do 500 tys. mieszkańców.

W procesie badania, próbowano określić stan wiedzy oraz główne źródła informacji respondentów na temat żywności regionalnej i tradycyjnej. Najczęstszym źródłem informacji na temat tej żywności, była wiedza zaczerpnięta z Internetu (47\%), jak również informacje zawarte na opakowaniach produktów (34\%). Poza tym ważnym źródłem, była wiedza pozyskana od sprzedawców zarówno w sklepach specjalistycznych, jak i przy okazji uczestnictwa nabywców w regionalnych targach, kiermaszach, czy jarmarkach. Najmniej osób czerpie informacje z reklam oraz z w bloków tematycznych emitowanych w telewizji (8\%) i w radio (7\%) (rys. 2)

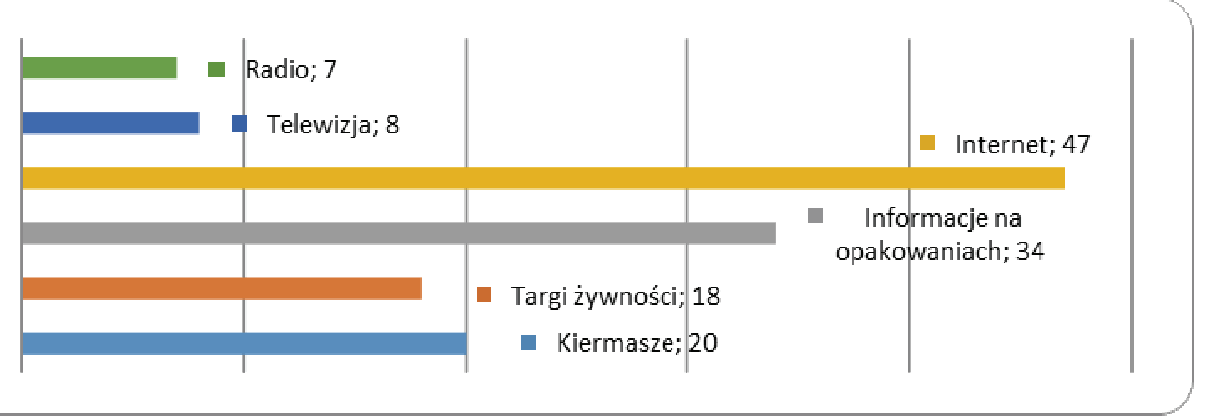

Rys. 2. Źródła czerpania informacji na temat żywności tradycyjnej i regionalnej

Fig. 2. Sources of information on traditional and regional food

Źródło: Opracowanie własne.

Porównując uzyskane odpowiedzi respondentów z wcześniejszymi wynikami badań m.in. Grębowca (2012), można wywnioskowac, że telewizja nie jest już współcześnie dominującym żródłem wiedzy o tego typu produktach, a coraz większego znaczenia nabiera Internet. Spowodowane jest to m.in. niewystarczająca jak dotąd skala 
promocji produktów regionalnych oraz małą ilością programów tematycznych w telewizji. Natomiast coraz intensywniej rozwija się markating tego typu produktów w Internecie. Coraz więcej osób dowiaduje się także o walorach produktów regionalnych i tradycyjnych od producentów lub sprzedawców na jarmarach, czy targach.

Z kolei z badań przeprowadzonych w 2009 roku przez Jeżewskią-Zychowicz wynika, że głównym źródłem wiedzy na temat produktów regionalnych i tradycyjnych była telewizja (35\%). Ponadto wymieniono także informacje pozyskiwane od znajomych i rodziny (33\%) oraz z lokalnych kiermaszów (18\%). Najmniej konsumenci dowiadują się na temat produktów regionalnych i tradycyjnych z radia 4\% (JeżewskaZychowicz, 2009).

Zdaniem Borowskiej głównym źródłem informacji na temat produktów regionalnych i tradycyjnych są według 41\% badanych przez Autorke programy telewizyjne, na drugiej pozycji wymieniano przekazy ustne oraz rekomentacje rodziny. Prawie co piąty badany dowiedział się o nich podczas targów, jarmarków, wystaw czy kiermaszy a także ze źródeł pisanych - prasy czy ulotek. Co dziesiąty zaś respondent wskazywał informację pozyskaną podczas spotkania z producentem (Borowska, 2008).

Jak piszą Paluch i Stromny, ludność wiejska czerpie informacje na temat produktów regionalnych i tradycyjnych głównie $\mathrm{z}$ ekspozycji w sklepach lub miejscach sprzedaży, a ludność miejska w restauracjach i targach regionalnych kiermaszach (Paluch, Stoma, 2015).

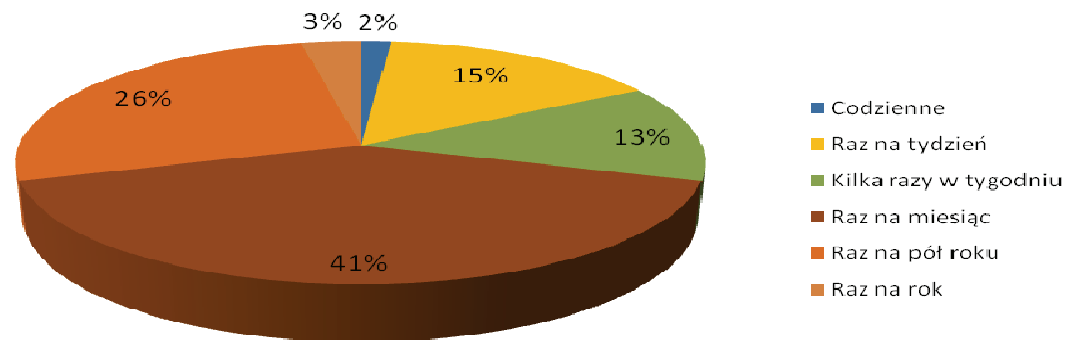

Rys. 3. Częstotliwość nabywania produktów regionalnych i tradycyjnych

Fig.3. The frequency of acquiring regional and traditional products

Źródło: Opracowanie własne

Kolejne pytanie zawarte w kwestionariuszu miało na celu określenie częstotliwości nabywania produktów regionalnych i tradycyjnych. Badania wykazały, iż produkty regionalne nabywane są nadal zbyt rzadko w stosunku do korzyści związanych z ich konsumpcją. Najczęściej powtarzała się odpowiedź, iż respondenci nabywali produkty regionalne co najmniej raz na miesiąc 41\%. Znaczna część badanych (26\%) wskazała, że kupuje tego typu produkty raz na pół roku. Wśród badanych byli i tacy którzy deklarowali nabywanie produktów regionalnych raz na tydzień $15 \%$ (najwięcej w wieku 31-50). Najmniej osób odpowiedziało że nabywa produkty regionalne i tradycyjne kilka 
razy w tygodniu (13\%), raz na rok (3\%), zaś codzienne nabywanie deklarowało jedynie $2 \%$ respondentów (rys. 3 ).

Respondenci mieli także za zadanie określić czynniki, które skłoniły by ich do częstszego nabywania tych produktów. Wskazywali oni najczęściej na łatwiejszy dostęp do produktów $52 \%$ i niższą cenę $49 \%$. Wskazywano także na konieczność większego upowszechniania wiedzy na temat tego typu żywności (21\%), jak również praktycznego podejścia do promocji tych produktów, za sprawą umożliwienia degustacji i możliwości częstszego i szerszego porównania z żywnością konwencjonalną. Najmniejszy wpływ spośród podawanych cech miały posiadane przez producentów certyfikaty $7 \%$. Ostatnie ze wspomnianych spostrzeżeń może wskazywać na wciąż niewystarczającą wiedzę na temat tego typu świadectw wśród badanych. Co dowiedziono w dalszej części badań (rys. 4).

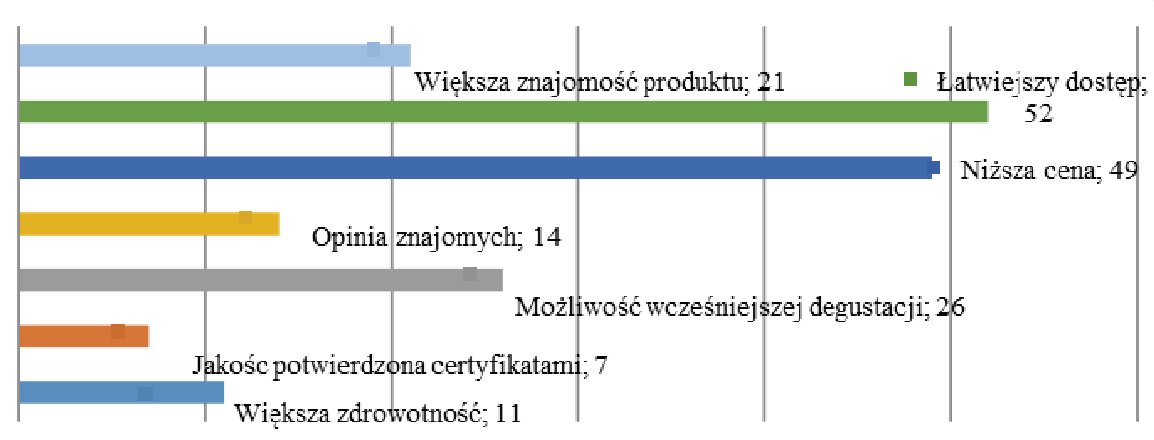

Rys. 4. Czynniki które wpłynęły by na częstsze nabywanie produktów regionalnych i tradycyjnych

Fig. 4. Factors that would have affected more often the acquisition of regional and traditional products

Źródło: Opracowanie własne

$\mathrm{Na}$ podstawie badań Paluch i Stomy (2015), w których udział wzięło stu ankietowanych, można stwierdzić, że respondenci ocenili cenę produktów regionalnych jako bardzo wysoką lub wysoką (68\%). Dla $26 \%$ respondentów była ona odpowiednia, a żaden ankietowany nie zaznaczył odpowiedzi bardzo niska lub niska. Ceny produktów tradycyjnych i regionalnych kształtują się na wysokim poziomie z powodu tradycyjnych metod produkcji, co za tym idzie koszty produkcji są wysokie, a produkcja masowa niemożliwa (Paluch, Stoma, 2015).

Wziąwszy pod uwagę najczęstsze miejsca nabywania żywności tradycyjnej i regionalnej, wyniki nie są jednoznaczne, bardzo duża ilość osób kupuje ją na targach i bazarach (48\%), na jarmarkach i festiwalach zdrowej żywności (38\%) oraz bezpośrednio u producenta (36\%). Warto zaobserwować, że bardzo mała ilość osób kupuje je w supermarketach/ hipermarketach. Porównując odpowiedzi respondentów z wcześniejszymi wynikami badań Grębowca (2012) można wywnioskować, że zwiększyła się ilość nabywanych produktów tradycyjnych i regionalnych na targach, bazarach, jarmarkach i festiwalach zdrowej żywności. Coraz większego znaczenia nabierają jednak zakupy przez Internet szczególnie wśród osób młodych.

Biorąc pod uwagę podobne badania Żakowskiej-Biemans, najczęściej wskazywanym miejscem zakupu produktów regionalnych i tradycyjnych były pobliskie 
sklepy spożywcze, supermarkety oraz bazary i targowiska, ale również sklepy specjalistyczne, np. z żywnością tradycyjną i ekologiczną (Żakowska-Bielmans, 2012).

Badania wykazały też, że zakup żywności regionalnej i tradycyjnej ma bardzo często charakter incydentalny i okazjonalny. Badani deklarowali że najczęściej dokonują zakupu tych produktów podczas pobytu w regionie ( $44 \%$ ankietowanych). Poza tym ważną informacją było to, że nabywcy produkty te bardzo często traktują jako niezwykle ekskluzywne nabywając je z okazji świąt i ważnych uroczystości rodzinnych odpowiednio $21 \%$ i $12 \%$ odpowiedzi (rys. 5).

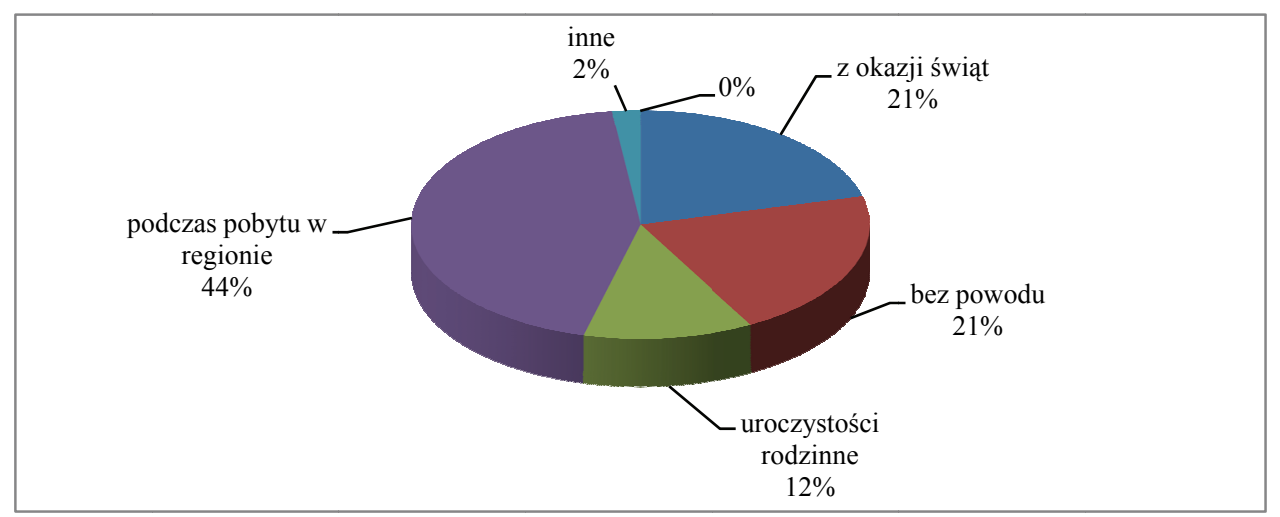

Rys. 5. Okoliczności nabywania produktów regionalnych i tradycyjnych

Fig. 5. Circumstances of acquiring regional and traditional products

Źródło: Opracowanie własne.

Badani zostali także poproszeni o ocenę najbardziej cenionych cech produktów tradycyjnych i regionalnych, w zależności od upodobania w skali od 1-5, gdzie 5 uznano za najbardziej istotną cechę. Na podstawie uzyskanych wyników można wywnioskować, że konsumentom jak najbardziej odpowiada smak i zapach produktów regionalnych $(4,2)$. Ponadto jako ważną cechę podano niepowtarzalność i cechy jakościowe związane z regionalizacją danego dobra żywnościowego, podkreślającego tradycje i smaki kulinarne kultywowane przez lata $(4,2)$. Ważną cechą na którą zwracano uwagę w procesie wyboru żywności regionalnej i tradycyjnej była także chęć urozmaicenia i wzbogacenia codziennego jadłospisu o żywność uchodzącą potocznie za smaczną i zdrową $(3,6)$.

Badania Minty, Tańskiej-Hus i Kapały (2012) wskazują także najczęstsze powody nabywania oraz istotne cechy produktów tradycyjnych i regionalnych. Dla największej ilości respondentów wysoka jakość i bezpieczeństwo są najczęstszym powodem zakupu produktów regionalnych ( $20 \%$ ankietowanych). Natomiast takie czynniki jak: szukanie odmiany podczas podróży, chęć poznania lokalnych tradycji, sprawdzenie pochodzenia produktu oraz chęć wsparcia lokalnych produktów stanowiły 49\% odpowiedzi ankietowanych. Co oznacza, że dla polskiego konsumenta istotnym czynnikiem może być oprócz walorów użytkowych i zdrowotnych, chęć poznania kultury danego regionu, tradycji, obyczajów oraz otwartość na nowości kulinarne (Minta i in., 2014).

W celu zbadania znajomości znaków jakości respondenci proszeni byli także, aby przyporządkowali dany znak graficzny do nazwy. Przeprowadzone badania wykazały że 
najbardziej rozpoznawalnym znakiem jest Chroniona Nazwa Geograficzna 58\% ankietowanych zaznaczyło dobrą odpowiedz (głównie osoby w wieku 18 - 30). Natomiast prawie co drugi ankietowany nie potrafił przyporządkować odpowiedniej nazwy do znaku graficznego. Co potwierdza wyżej wspomnianą tezę o wciąż słabej znajomości i identyfikowalności oznaczeń produktów regionalnych i tradycyjnych wśród nabywców. Z przeprowadzonych w 2014 roku na podobny temat badań przez Mintę wynikają podobne wnioski. Mianowicie rozpoznawalność nazw produktów regionalnych $\mathrm{i}$ tradycyjnych jest nadal na przeciętnym poziomie. Aż 54\% ankietowanych nie potrafiło wymienić ani jednej nazwy produktu regionalnego, po wcześniejszej deklaracji, że zna takie produkty. Tylko $13 \%$ ankietowanych potrafi podać dwie lub więcej nazw produktów, a 33\% podało tylko jedną prawidłową (Minta i in., 2014).

\section{Podsumowanie}

Przedstawione rozważania podkreślają rolę produktów regionalnych i tradycyjnych w kształt funkcjonowania Wspólnej Polityki Rolnej dotyczącej rozwoju wsi i rolnictwa. Produkty te są elementem zarówno budowania tożsamości narodowej wielu regionów UE, które zajmują się ich produkcją i sprzedażą. Ponadto oryginalne (niepodrobione) produkty regionalne $\mathrm{i}$ tradycyjne $\mathrm{z}$ punktu widzenia nabywców uchodzą wciąż za produkty o niepowtarzalnych walorach smakowych, użytkowych, ale także bezpiecznych dla zdrowia. Jednak świadomość ich istnienia i pełnej identyfikacji jest jak wykazały przeprowadzone m.in. przez Autora badania, współcześnie wciąż niewystarczająca. Dzieje się tak głównie za sprawą wciąż niskich nakładów na promocję tego typu produktów, szczególnie jeśli chodzi o rodzime, polskie produkty. Problemem jest także niska skala produkcji, aby te jednostki produkcyjne mogły by skutecznie konkurować z producentami żywności tzw. „konwencjonalnej”. Ponadto wciąż wyraźnie zarysowują się istotne niedoskonałości związane ze sprzedażą tego typu dóbr. Jedną z recept na przełamanie tego impasu może być Internet, który współcześnie jest ważnym instrumentem nie tylko w procesie sprzedaży, ale również promocji tejże żywności.

Produkty tradycyjne i regionalne cieszą się wciąż niestety przeciętną popularnością wśród badanych konsumentów, szczególnie u osób w podeszłym wieku. Natomiast możliwości sukcesu na rynku produktów regionalnych i tradycyjnych są znaczne, ponieważ dobra te bardzo dobrze kojarzą się $\mathrm{z}$ takimi określeniami jak: naturalne, $\mathrm{o}$ wyjątkowych walorach smakowo - zapachowych, wysokiej jakości i wyższej wartości odżywczej. Dlatego też należy dołożyć wszelkich starań na drodze szerszego rozpropagowania idei produkcji, a szczególnie spożycia żywności regionalnej i tradycyjnej, która to jest nie tylko jest zdrowa i bezpieczna, ale także zawiera pierwiastek lokalnego patriotyzmu. 


\section{Literatura}

Borowska, A. (2008). Postawy europejskich konsumentów wobec produktów tradycyjnych i regionalnych. ZN SGGW Ekonomika i Organizacja Gospodarki Żywnościowej, 72, 145-159.

Borowska, A. (2009). Tendencje zmian na rynku tytoniowym w Polsce w latach 1990-2006. ZN SGGW Ekonomika i Organizacja Gospodarki Żywnościowej, 73, 145-150.

Czarnecki, K. (2012). Produkcja i podaż produktów regionalnych, Roczniki Naukowe SERiA, 14(1), 99-102.

Czyż, T. (2009). Konkurencyjność regionu wielkopolskiego w aspekcie gospodarki opartej na wiedzy. Charakter regionalny województwa wielkopolskiego, Biuletyn nr 9, Wydział Nauk Geograficznych i Geologicznych, Instytut Geografii Społeczno-Ekonomicznej i Gospodarki Uniwersytetu Adama Mickiewicza, Poznań, 77-95.

Faulkner, D., Bosman, C. (1996). Strategie konkurencji, Gebethner i s-ka, Warszawa.

Golejewska, A., Gajda, D. (2012). Analiza potencjału konkurencyjnego polskich regionów, Analizy i Opracowania Katedry Ekonomiki Integracji Europejskiej Uniwersytetu Gdańskiego, 05/2012 (015).

Grębowiec, M. (2010). Rola produktów tradycyjnych i regionalnych w podejmowaniu decyzji nabywczych przez konsumentów na rynku dóbr żywnościowych w Polsce. ZN SGGW Problemy Rolnictwa Światowego, 10(2), 22-31.

Grębowiec, M. (2013). Produkty regionalne i tradycyjne ora ich rola w budowaniu konkurencyjnej oferty regionów. Roczniki Naukowe SERiA, 15(2), 81-85

http://coie.armsa.pl/Mazovian,regional,products, 130.html. Pobrano w dniu 23.01.2017.

Jeżewska-Zychowicz, M., Babicz-Zielińska, E., Laskowski, W. (2009). Konsument na rynku nowej żywności. Wybrane uwarunkowania spożycia, SGGW, Warszawa.

Konkurencyjność produktów tradycyjnych i regionalnych (2014). Pobrano 25 kwietnia 2014 z: www.ankietka.pl.

Krajewski, K., Tul-Krzyszczuk, A., Kondraciuk, P., Świątkowska, M. (2009). Doświadczenia i znaczenie produktów tradycyjnych w promocji regionów turystycznych. W: Z.J. Dolatowski, D. KołożynKrajewska (red.) Rozwój turystyczny regionów a tradycyjna żywność, Wyższa Szkoła Hotelarstwa i Turystyki Częstochowa i Polskie Towarzystwo Technologów Żywności.

Krajewski, K., Zabrocki, R. (2008). Rynek produktów tradycyjnych - szanse, potrzeby, możliwości. W: Tradycyjne i regionalne technologie oraz produkty w żywieniu człowieka, pod red. Z. Dolatowski, J. Kołożyn-Krajewska, Wyd. Naukowe PTTŻ Kraków.

Minta, S., Tańska-Hus, B., Kapała, A. (2014). Consumer awareness of regional products - selected research results. Roczniki Naukowe SERiA, 16(4), 195-200.

Mynarski, S. (2001). Badania rynkowe w przedsiębiorstwie, Wyd. Akademii Ekonomicznej w Krakowie.

Paluch, A, Stoma, M. (2014). Analiza możliwości rozwoju produkcji oraz rynku produktów regionalnych i tradycyjnych w województwie lubelskim. Acta Scientarum Polonorum Technica Agraria 13(3-4), 37-47.

Przybylak, K. (2013). Jak sprzedawać aby odnieść sukces? W: Włoszczowski T. (red.) Produkt tradycyjny i lokalny: promocja, marka, dystrybucja - przykłady dobrych praktyk" realizowanym w ramach Planu Działania Sekretariatu Centralnego Krajowej Sieci Obszarów Wiejskich lata 2012-2013, Warszawa.

Richter-Kaźmierska, A. (2007). Partnerstwo na rzecz rozwoju regionalnego a konkurencyjność regionalna. W: T. Biernat (red.), Przedsiębiorstwo i państwo - wybrane problemy konkurencyjności, Katedra Mikroekonomii Uniwersytetu Szczecińskiego, Szczecin.

Russak, G. (2005). Idea produktów regionalnych lokalnych w Unii Europejskiej. W: Gąsiorowski M. (red.) O produktach tradycyjnych i regionalnych. Możliwości, a polskie realia, Fundacja Fundusz Współpracy, Warszawa.

Rzytki, M., Jasiński, J. (2005). Produkty regionalne, Fundacja Fundusz Współpracy, Warszawa.

Sieczko, A. (2008). Tworzenie rynku produktów tradycyjnych i regionalnych, ZN SGGW Problemy Rolnictwa Światowego, 4(19), 397-407.

Sieczko, A. (2014). Produkty regionalne i tradycyjne w promocji regionów. Turystyka i Rozwój Regionalny, $2,79-89$.

Stasiak, A. (2015). Rozwój turystyki kulinarnej w Polsce. W: Kultura i turystyka - wokół wspólnego stołu, Kowalczyk A, Stasiak A, 119-149.

Sylvander, B. (2002). WP3 Final Report - Link between Origin Labeled Products and rural development. Concerned Action DOLPHINS (Development of Origin Labelled Products: Humanity, Innovation and Sustainability), INRA-UREQUA, Le Mans, France, 7-9. 
Świstak, E., Bilska, B., Stępień, A., Tul-Krzyszczuk, A. (2013). Produkty regionalne jako element budowania konkurencyjności obszarów wiejskich. W: K. Krzyżanowska (red.), Budowanie konkurencyjności obszarów wiejskich, Wyd. SGGW, Warszawa, 139-148.

Winawer, Z. (2013). Produkt tradycyjny i lokalny: promocja, marka, dystrybucja - przykłady dobrych praktyk. Realizowanym w ramach Planu Działania Sekretariatu Centralnego Krajowej Sieci Obszarów Wiejskich

www.ekoefekt.pl/publikacje,14,ochrona-i-promocja-produktow-regionalnych-i-tradycyjnych-.html. Pobrano w dniu: 17.11.2016 r.

Żakowska-Biemans, S. (2012). Żywność tradycyjna z perspektywy konsumentów. Żywność. Nauka. Technologia. Jakość, 3(82), 5-18. 